\title{
Metal Accumulation in Blood Plasma and in Femora of Feral Pigeon (Columba livia) Free Living in Smelting, Urban and Rural Area in Kosovo
}

\author{
Sheval F. Memishi ${ }^{1 *}$, Kasum Rr. Letaj², Qerim I. Selimi ${ }^{3}$, Isa R. Elezaj ${ }^{2}$ \\ ${ }^{1}$ Faculty of Natural and Mathematical Sciences, University of Tetovo, Republic of North Macedonia \\ ${ }^{2}$ Faculty of Natural and Mathematical Sciences, University of Prishtina "Hasan Prishtina"; \\ Str. Eqrem Çabej, Nr. 54, 10000 Prishtina Republic of Kosovo \\ ${ }^{3}$ Faculty of Education, University of Mitrovica "Isa Boletini"; Rr. parku industrial, \\ p.n 40000 Mitrovicë, Republic of Kosovo;
}

Received: 10 June 2019

Accepted: 21 August 2019

\begin{abstract}
The purpose of this study was to estimate the effect of environmental pollution in level of B, $\mathrm{Ba}, \mathrm{Fe}, \mathrm{Mg}, \mathrm{Mn}, \mathrm{Pb}, \mathrm{Sr}$ and $\mathrm{Zn}$, in blood plasma and in femora of Feral pigeons (Columba livia) in three localities: Mitrovica town-industrial area, Peja town- urban area and Lukina village- rural area. The plasma level of $\mathrm{Ba}$ in pigeons from Mitrovica is higher than in pigeons from Peja and Lukina. The plasma level of $\mathrm{Fe}, \mathrm{Mg}$ and $\mathrm{Zn}$ of Mitrovica pigeons, is moderately higher than in Peja and Lukina. The concentration of $\mathrm{Ba}, \mathrm{Fe}, \mathrm{Sr}$ and $\mathrm{Zn}$ in femora of pigeons from Mitrovica is higher than in Lukina. $\mathrm{B}, \mathrm{Fe}, \mathrm{Mg}, \mathrm{Mn}, \mathrm{Sr}$ and $\mathrm{Zn}$ concentration in femora of Peja pigeons, are higher than in Lukina, while B, $\mathrm{Fe}, \mathrm{Mn}, \mathrm{Sr}$ and $\mathrm{Zn}$ are higher than in Mitrovica. The $\mathrm{Pb}$ concentration in femora of Mitrovica pigeons, is critically higher. The accumulation of $\mathrm{Ba}$ in blood plasma and concentration of $\mathrm{B}, \mathrm{Ba}, \mathrm{Mg}, \mathrm{Mn}, \mathrm{Pb}$, $\mathrm{Sr}$ and $\mathrm{Zn}$, in femora of Mitrovica pigeons, draws attention to the potential hazard to the children of that area. Feral pigeons can be useful organisms for chronic evaluation of environmental pollution with heavy metals.
\end{abstract}

Keywords: Feral pigeons, plasma, blood, femora, heavy metals

*e-mail: sheval.memishi@unite.edu.mk 


\section{Introduction}

Pollution of ecosystems by man-made chemicals is increasing in highly industrialized and developing countries. Of the other hand, urbanization is expanding worldwide, with over $50 \%$ of humans now inhabiting urban areas. Urban ecosystems are polluted as a consequence of urbanization and industrial processes [1-4]. Therefore, pollution assessment by monitoring is of paramount importance [5]. When metals are released into the environment by human activities, they reside for a long time in soil and water, and exert harmful effects on ecosystems long after the source of pollution has ceased to operate. They accumulate in different animal and human tissues such as: blood, liver, kidney, bones and feathers [6-8].

In this context, birds living in close proximity with human activities (synanthropic organisms) which are sedentary and closely associated with urban environments, represent useful biological models for evaluating heavy metal contamination in urban and industrial-polluted areas. Among them, feral pigeons have settled in the cities and are widely distributed around the world [9].

In the United Kingdom, studies of lead accumulation in the Feral pigeon (Columba livia), suggest that the use of this species as an indicator organism would facilitate periodic monitoring of chronic lead exposure conditions of the urban environments that cannot readily be achieved through laboratory investigations [10]. This sedentary species forms discrete flocks with specific feeding and roosting areas and is therefore a potentially useful index of lead exposure at a local geographical level.

Feral pigeons (Columbia livia) exhibit strong site fidelity to their birth sites, generally remaining in a small area $(<2 \mathrm{~km})$ for their entire lives [10]. This trait makes them useful for investigating the geographic spread of bio available toxicants with a high level of location specificity [6].

Several studies have documented contamination with heavy metals in feral pigeons from urban and industrial areas [11].

Feral pigeon (Columba livia) and House sparrow (Passer domesticus) have been studied in the pollution gradient from the Trepça smelter since the year 2000 $[5,12-14]$, and has indicated that reduced atmospheric emissions resulted in reduced exposure of metals in these bird species, free living in Mitrovica town which is close to Trepça smelter. Although the accumulation of $\mathrm{Pb}$ in bone tissue of Feral pigeons from Mitrovica showed progressive decreased accumulation of $\mathrm{Pb}$ from 2000 and 2013, the $\mathrm{Pb}$ concentration in the blood and bone was several times higher compared with $\mathrm{Pb}$ concentration in the reference group of birds $[5,12]$.

Our primary objective of the present study was to determine the levels of $\mathrm{Ba}, \mathrm{Fe}, \mathrm{Mg}$, and $\mathrm{Zn}$ in blood plasma, and the concentrations of $\mathrm{B}, \mathrm{Ba}, \mathrm{Fe}, \mathrm{Mg}, \mathrm{Mn}$, $\mathrm{Pb}, \mathrm{Sr}$ and $\mathrm{Zn}$ in femora of the feral pigeon (Columba livia) population living in different areas Mitrovica in close vicinity to the former smelter Trepça, Peja town (urban polluted area) and Lukina village (rural unpolluted area).

\section{Material and Methods}

Mitrovica had the largest metallurgic and mining complex in Europe, Trepça, which commenced activities in 1993 with the extraction of lead, cadmium and zinc. Many industrial plants existed in the complex such as a lead smelter, fertilizer production plant, refinery, battery factory, zinc electrolysis facility and a sulfuric acid plant. A significant amount of heavy metal pollutants were released to the surrounding area, including populated residential areas and therefore associated with health risk of biota and humans [15].

The presence of the smelter and three huge tailing dams led to a drastic increase in environmental contamination in Mitrovica. The smelter had been in operation intermittently since 1999. However, an environmental audit ordered by the United Nations Interim Administration Mission in Kosovo (UNMIK), conducted in March and April 2000, warned that the smelter should be closed as an "unacceptable" source of air contamination [16]. Total Trepça production from 1931 to 1998 has been estimated at 34,350,000 t run-ofmine ore, at grades of $6 \% \mathrm{~Pb}$ and $4 \% \mathrm{Zn}$. Several reports have indicated that current levels of lead exposure are extremely high in soil and air [16].

According to concern about environmental contamination and its health risk, the complexes were shut down in July 2000 by the UN. However, lead and other heavy metals such as cadmium, nickel, arsenic and zinc from the abandoned waste tailing dams and contaminated soil from mining and smelting activities continuously influence the environment and cause adverse health effects in the people in this area. The data of investigation from the narrower vicinity of Mitrovica show that the average content of $\mathrm{Pb}$ in soil is 20-fold higher than the European median; Cd 11-fold, $\mathrm{Hg}$ 5.5-fold, As 4.6-fold, $\mathrm{Zn} 4.2$ and $\mathrm{Cu}$ 3.2-fold higher. In the narrower vicinity of Mitrovica and Zveçan, the content of the aforementioned elements is even higher than the intervention values, according to the New Dutch list, and were exceeded in $152 \mathrm{~km}^{2}$ of the investigated area. In the narrower vicinity of Mitrovica and Zveçan, the content of the aforementioned elements is even higher than the intervention values, according to the New Dutch list, and were exceeded in $152 \mathrm{~km}^{2}$ of the investigated area $[15,16]$.

Birds, including feral pigeon and house sparrow living around $\mathrm{Pb}-\mathrm{Zn}$ mining areas in the Mitrovica region, have shown high levels of heavy metal poisoning [17].

Peja town is located in northern Kosovo, around the geographical coordinates $42^{\circ} 39 \mathrm{~V}$ and $20^{\circ} 18 \mathrm{~L}$., with about 96.500 inhabitants. In the past, the city 


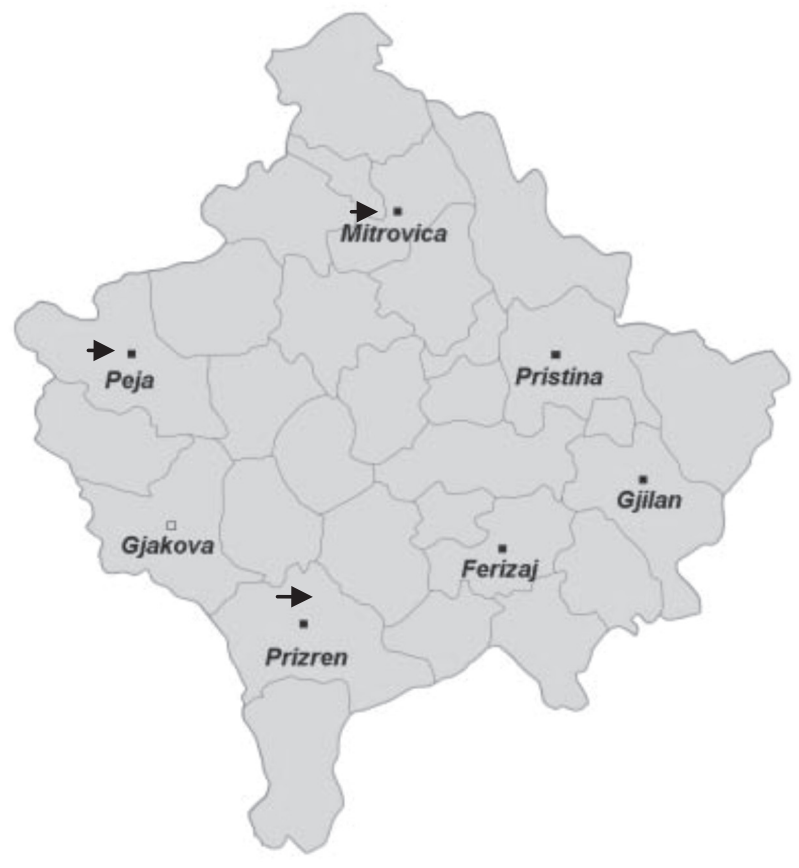

Fig. 1. Map of the study area showing Mitrovica-smelting area, Peja-urban area and Lukina-rural area-Prizren municipality in the Republic of Kosovo.

was on the important trade route between Dubrovnik and Istanbul. However, Peja maintains its status as the northern traffic junction of the landscape Rrafshi i Dukagjinit.

The only direct transport links from Kosovo to Montenegro continue to be via Peja - to Rozhajë in the north and to Andrijevica in a westerly direction. To the south, a main road leads via Deçan and Gjakova to Prizren, to the east a main road to Prishtina. Following the 1999 conflict, vehicle numbers in Kosovo have drastically increased. The total amount of vehicles in Kosovo is 300000 approximately (source: Statistical Office of Kosovo). From the Kosovo total registered vehicles, 100000 are registered in the town of Peja. The petrol in Kosovo, still contain alkyl lead compounds as an anti-knocking agent.

Lukina village (agro rural area) is located in southwestern Kosovo, 10 km from Prizren (Fig. 1).
Specimens of feral pigeon (Columba livia) were collected in March 2017 in three different localities: Mitrovica (smelter-polluted area; 20 birds - males and females), Peja (urban polluted area; 20 birds - males and females) and Lukina village (rural unpolluted area; 20 birds - males and females).

In the laboratory, blood samples were collected in heparinyzed tubes with siring directly from heart, after first removing feathers in the area and thoroughly cleaning the skin. Birds were then sacrificed by cervical dislocation and the femora excised, precautions being taken to prevent metal contamination.

The blood plasma was extracted after tube centrifugation. The level of metals in blood plasma was analyzed by induction-coupled plasma linked with an atomic emission spectrometer ICP-AES (715ES, Varian). For this purpose, $5 \mathrm{ml}$ of the plasma were diluted in $5 \mathrm{ml}$ of concentrated nitric acid, $\mathrm{HNO}_{3}$ and in $2 \mathrm{ml}$ of hydrogen peroxide, $\mathrm{H}_{2} \mathrm{O}_{2}(30 \%, \mathrm{~m} / \mathrm{V})$. Teflon tubes were carefully sealed and a method of digestion was used. The digestion method was accomplished in two steps for total sample dissolution. The digested samples were then diluted with DDW to a volume of $25 \mathrm{ml}$ and analyzed.

Femur bones were isolated, taking care in advance to prevent possible contamination with metals. Isolated femurs were dried in a thermostat at $105^{\circ} \mathrm{C} / 48$ hours. After being ground in the mortar for sample digestion, dried femora tissue samples of $0.5 \mathrm{~g}(0.5 \mathrm{~g}$ with accuracy of 0.0001) are transferred in the teflon tubes, into which $5 \mathrm{ml}$ of concentrated nitric acid was added, along with $\mathrm{HNO}_{3}$ and $2 \mathrm{ml}$ of hydrogen peroxide, $\mathrm{H}_{2} \mathrm{O}_{2}(30 \%, \mathrm{~m} / \mathrm{V})$. Teflon tubes were carefully sealed and digestion was performed by microwave digestion system on March 5.

The digestion method was accomplished in two steps for total tissue dissolution. The digested samples were then diluted with DDW to $25 \mathrm{ml}$ volume and analyzed. The determination of metals in the tissue were analyzed by induction-coupled plasma and linked with atomic emission spectrometer ICP-AES (715ES, Varian) at the Chemical Institute, University "Cyril and Methodius" in Skopje, Macedonia.

Statistical analysis of the results was carried out with Sigma stat 32 programs (2004 STAT Software).

Table 1. Level of metals in blood plasma ( $\mathrm{mg} / \mathrm{L}$ ) of feral pigeons (Columba livia) from three different localities.

\begin{tabular}{|c|c|c|c|c|c|}
\hline \multicolumn{5}{|c|}{ Localities } \\
\hline Metals & LOD (mg/L) & Lukina (L) (rural area) & Peja (P) (urban area) & Mitrovica (M) (smelting area) & P $<$ significance \\
\hline $\mathrm{Ba}$ & 0.001 & $0.015 \pm 0.008$ & $0.012 \pm 0.009$ & $0.035 \pm 0.033$ & $\begin{array}{c}\text { M:P } ; \mathrm{P}<0.001 \\
\text { M:L; P }<0.01\end{array}$ \\
\hline $\mathrm{Fe}$ & 0.01 & $1.58 \pm 0.86$ & $1.65 \pm 0.87$ & $1.89 \pm 1.65$ & NS \\
\hline $\mathrm{Mg}$ & 1 & $19.9 \pm 3.8$ & $18.4 \pm 2.9$ & $20.5 \pm 4.2$ & $\mathrm{NS}$ \\
\hline $\mathrm{Zn}$ & 0.001 & $2.68 \pm 0.71$ & $2.89 \pm 0.74$ & $2.55 \pm 0.72$ & $\mathrm{NS}$ \\
\hline
\end{tabular}

Note: LOD-limit of detection; NS-Non significant 


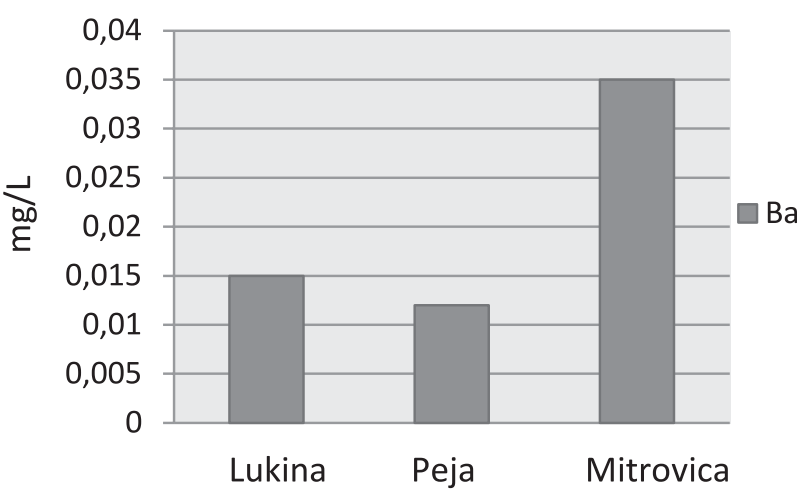

Fig. 2. Levels of $\mathrm{Ba}$ in blood plasma of feral pigeons (Columba livia) in three different localities.

For each continuous variable, a distribution form was determined, and significant differences between means were checked by Student's t-test. P value $<0.05$, twosided was considered statistically significant, and Spearman's correlation with a probability of $<0.005$ or less.

\section{Results and Discussion}

The results of the level of some elements (Ba, $\mathrm{Fe}, \mathrm{Mg}$, and $\mathrm{Zn}$ ) in the blood plasma of feral pigeons (Columba livia) from three different localities (Lukina, Peja and Mitrovica) are presented in Table 1 and Fig. 2.

The results show that the level of $\mathrm{Ba}$ in the plasma of feral pigeons from Mitrovica was significantly higher compared with level in blood plasma of Peja and Lukina ( $\mathrm{P}<0.001 ; \mathrm{P}<0.01$ respectively). On the other hand, the plasma levels of $\mathrm{Fe}, \mathrm{Mg}$, and $\mathrm{Zn}$, in plasma of Feral pigeons between the groups were close to physiological norms.

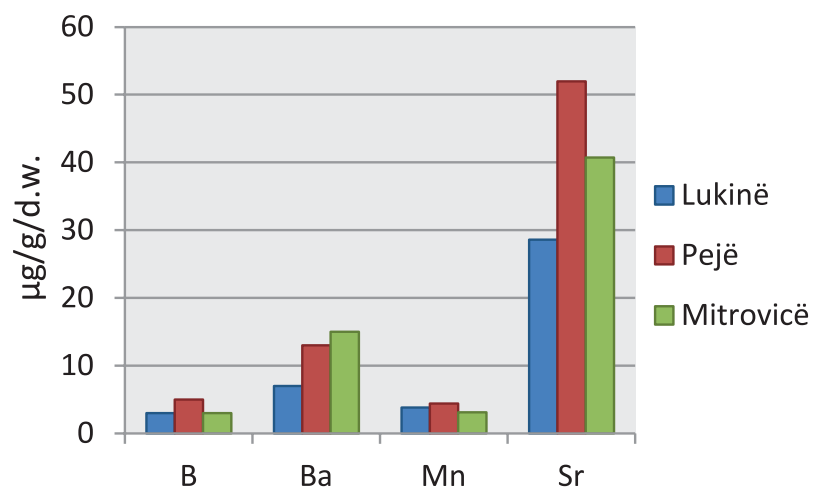

Fig. 3. Concentrations of $\mathrm{B}, \mathrm{Ba}, \mathrm{Mn}$ and $\mathrm{Sr}$ in femora of feral pigeons (Columba livia) in three different localities.

The concentrations of $\mathrm{B}, \mathrm{Ba}, \mathrm{Fe}, \mathrm{Mg}, \mathrm{Mn}, \mathrm{Pb}, \mathrm{Sr}$ and $\mathrm{Zn}$ in femora of feral pigeons (Columba livia) from Lukina, Peja and Mitrovica are presented in Table 2 and Figs 3-4.

The concentration of $\mathrm{B}$ in femora of pigeons from Peja was significantly higher $(\mathrm{P}<0.02)$ compared with Lukina and Mitrovica (Table 2, Fig. 3). The concentrations of $\mathrm{Ba}, \mathrm{Fe}, \mathrm{Sr}$ and $\mathrm{Zn}$ in femora of Feral pigeons from Mitrovica were significantly higher $(\mathrm{P}<0.001 ; \quad \mathrm{P}<0.01 ; \quad \mathrm{P}<0.001 ; \quad \mathrm{P}<0.005$, respectively; Table 2, Figs 3-4), compared with the Lukina group. The concentrations of $\mathrm{Ba}, \mathrm{Fe}, \mathrm{Mg}, \mathrm{Sr}$ and $\mathrm{Zn}$ in femora of birds of Peja were significantly higher $(\mathrm{P}<0.001)$ compared with birds of Lukina, while the concentrations of $\mathrm{Fe}, \mathrm{Mg}$, Sr and $\mathrm{Zn}$ in femora of pigeons from Peja is significantly higher $(\mathrm{P}<0.001)$ compared with birds of Mitrovica (Table 2). The concentration of $\mathrm{Mn}$ in femora of pigeons from Peja was significantly higher $(\mathrm{P}<0.01)$ compared with birds in Mitrovica. The concentration of $\mathrm{Pb}$ in femora of Feral pigeons from Mitrovica is critically higher $(151 \mu \mathrm{g} / \mathrm{g} . \mathrm{d} . w$.$) , while the concentration$

Table 2. Concentrations of metals $(\mu \mathrm{g} / \mathrm{g} / \mathrm{d} . \mathrm{w})$ in femora of feral pigeons (Columba livia) from three different localities.

\begin{tabular}{|c|c|c|c|c|}
\hline \multicolumn{5}{|c|}{ Localities } \\
\hline Metals & Lukina (L) (rural area) & Peja (P) (urban area) & Mitrovica (M) (smelting area) & P< significance \\
\hline $\mathrm{B}$ & $3 \pm 1$ & $5 \pm 3$ & $3 \pm 0.6$ & P:L; P:M; $<<0.02$ \\
\hline $\mathrm{Ba}$ & $7 \pm 3.6$ & $13 \pm 6$ & $15 \pm 7$ & M:L; P:L; $\mathrm{p}<0.001$ \\
\hline $\mathrm{Fe}$ & $87 \pm 26$ & $139 \pm 47$ & $116 \pm 27$ & P:L; P:M; $\mathrm{p}<0.001$ \\
M:L; $\mathrm{p}<0.01$ \\
\hline $\mathrm{Mg}$ & $1728 \pm 305$ & $2341 \pm 464$ & $1724 \pm 306$ & P:L; P:M; $\mathrm{p}<0.001$ \\
\hline $\mathrm{Mn}$ & $3.8 \pm 3.0$ & $4.4 \pm 1.6$ & $3.1 \pm 0.6$ & P:M; $<<0.01$ \\
\hline $\mathrm{Pb}$ & $\mathrm{UD}$ & $\mathrm{UD}$ & $151 \pm 110$ & - \\
\hline $\mathrm{Sr}$ & $28.6 \pm 5.7$ & $52 \pm 15.6$ & $40.7 \pm 7.7$ & P:L; M:L; $\mathrm{P}<0.001$ \\
\hline $\mathrm{Zn}$ & $152 \pm 68.4$ & $233 \pm 211$ & $198 \pm 110$ & P:M:L; $\mathrm{p}<0.001$ \\
\hline
\end{tabular}

Note: UD-under limit of detection 


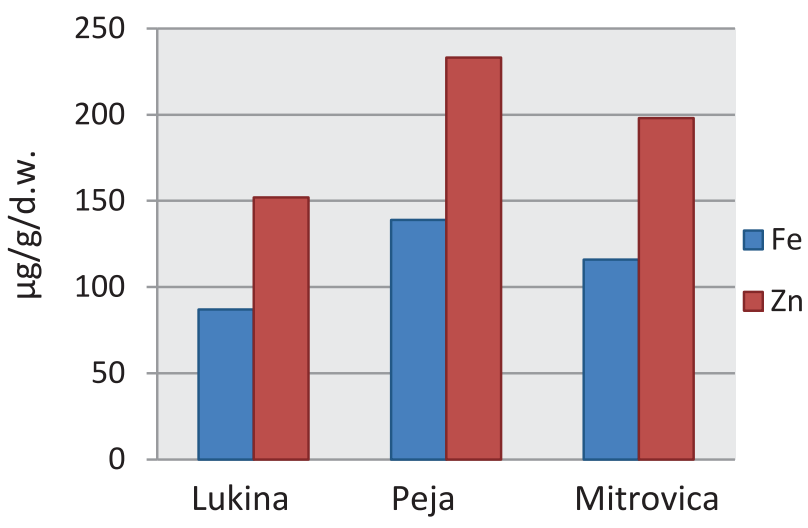

Fig. 4. Concentrations of $\mathrm{Fe}$ and $\mathrm{Zn}$ in femora of feral pigeons (Columba livia) in three different localities.

of $\mathrm{Pb}$ on the femora of pigeons from Peja and Lukina was under the limit of detection-LOD, $5 \mu \mathrm{g} / \mathrm{g}$. d. w. (Table 2).

Our results of higher concentrations of $\mathrm{Ba}$ and $\mathrm{Sr}$ in femora of feral pigeons (Columba livia), from Peja (urban area), and Mitrovica (in close vicinity to the Trepça smelter) are consistent with the results of [18], who established higher accumulation of $\mathrm{Ba}$ and $\mathrm{Sr}$ in bone, in comparison of their concentration in liver, kidney and muscle in great cormorants (Phalacrocorax carbo) from different colonies (lakes Biwa and Mie), in Japan.

Analyses of $\mathrm{Sr}$ and $\mathrm{Ca}$ concentrations and $\mathrm{Sr} /$ $\mathrm{Ca}$ ratios in eggshells from 20 avian species from California, Texas, Idaho, Kansas and Michigan [19] shoved higher $\mathrm{Sr}$ concentrations and $\mathrm{Sr} / \mathrm{Ca}$ ratios, and detected a highly significant linear relationship between $\mathrm{Sr} / \mathrm{Ca}$ values in eggshells and those in surface water from nearby regions. The $\mathrm{Sr}$ concentrations in blacknecked stilts (mean $=2.666 \pm 372 \mu \mathrm{g} / \mathrm{g}$ d. w.) from California are considered to be among the highest ever reported in avian eggshells.

Blum [20] studied the variability and biological fractionation of $\mathrm{Sr} / \mathrm{Ca}, \mathrm{Ba} / \mathrm{Ca}$ and ${ }^{87} \mathrm{Sr} /{ }^{86} \mathrm{Sr}$ ratios in a soil-plant-invertebrate-bird and food chain in two forested ecosystems, with contrasting $\mathrm{Ca}$ availability in northeastern U.S.A. Their results provide evidence that support about changes in $\mathrm{Sr} / \mathrm{Ca}, \mathrm{Ba} / \mathrm{Ca}$ and ${ }^{87} \mathrm{Sr} /{ }^{86} \mathrm{Sr}$ ratios between trophic levels in two forest ecosystems in the northeastern U.S.A. provide evidence that supports the use of $\mathrm{Sr} / \mathrm{Ca}$ ratios in the determination of human paleodiets, and suggests that $\mathrm{Sr} / \mathrm{Ca}$ ratios may also provide a useful tool in studies of modern food webs.

The presence of higher concentrations of $\mathrm{Sr}$ in femur of feral pigeons from the vicinity of Trepça smelter deserve attention, since strontium is strongly associated with calcium metabolism, thus calcium requirements for the female during egg production can result in increased calcium absorption in the gut as well as increased absorption of $\mathrm{Sr}$ and $\mathrm{Pb}$.

Budis [21] also established higher concentrations of Manganese (Mn), Iron (Fe) and Strontium ( $\mathrm{Sr})$ in bone of red fox (Vulpes vulpes, L. 1758), from West Pomeranian province, including its Capital, Szczecin, in northwest Poland.

Our results of higher concentrations of lead and zinc in femura of feral pigeons from Mitrovica are in accordance with the results of Elezaj [5, 14], who observed much higher concentrations of $\mathrm{Pb}, \mathrm{Zn}, \mathrm{Cu}$ and $\mathrm{Cd}$ in tibia, femur, kidney, liver, brain and heart of feral pigeons from the same area, not only in the year 2000 (when Trepça smelter was closed), but in four successive years (2000-2003) [14], and 12 years later [5].

The present results of $\mathrm{Pb}$ concentrations in femora of feral pigeons from Mitrovica $(151 \pm 110 \mu \mathrm{g} / \mathrm{g}$ d. w.), compared with $\mathrm{Pb}$ concentrations in femora of pigeons from the same area in 2000, 2001, 2002 and 2003, and in 2012, are several times lower: 2.1 times lower than in 2000, 4.6 times lower than in 2001, 1.4 times lower than in 2002, 4.1 times lower than in 2003, and 3.5 times lower than in $2012[12,14]$. By the year 2017, average femora $\mathrm{Pb}$ concentrations in feral pigeon form Mitrovica had decreased to $151 \pm 110 \mu \mathrm{g} / \mathrm{g}$ d.w. from $324 \pm 160 \mu \mathrm{g} / \mathrm{g}$ d.w. (in 2000), $696 \pm 255 \mu \mathrm{g} / \mathrm{g}$ d.w. in 2001, $212 \pm 250 \mu \mathrm{g} / \mathrm{g}$ d. w. in $2002,621 \pm 307 \mu \mathrm{g} / \mathrm{g}$ d.w. in 2003, and $530 \pm 583 \mu \mathrm{g} / \mathrm{g}$ d.w. in 2012 .

In our previous study [22], in the free living house sparrow (Passer domesticus) population from Mitrovica we established remarkable $\mathrm{Pb}$ concentrations in femora $(1756 \mu \mathrm{g} / \mathrm{g} \mathrm{d}$. w.), and $\mathrm{Cd}, \mathrm{Zn}$, and $\mathrm{Cu}$ in femora, tibia, sternum, kidney, liver, heart and brain.

Elezaj [23] established higher concentrations of $\mathrm{Pb}$, $\mathrm{Zn}$ and $\mathrm{Ni}$, in femora, tibia, liver and kidney of feral pigeons living in the courtyard of a fero-nickel smelter in Drenas-Kosovo.

Millaku [17], in the population of House sparrow (Passer domesticus), from the same area, 15 years after the Trepça smelter was closed down, recorded a higher concentration of $\mathrm{Pb}$ in femora $(506.8 \mu \mathrm{g} / \mathrm{g} \mathrm{d}$. w.), which is 3.4 times lower compared with femora $\mathrm{Pb}$ concentrations $(1756 \mu \mathrm{g} / \mathrm{g}$ d. w.) in house sparrow (Passer domesticus) determined in 2010 [22].

Nam and Lee [11], in the bone and kidney of resident feral pigeons from rural (island), central urban (Seoul), and four industrial complex areas in Korea with varying traffic densities, recorded mean concentrations of $\mathrm{Pb}$ and $\mathrm{Cd}$ of about 15-20 times those at the reference site. The $\mathrm{Pb}$ and $\mathrm{Cd}$ concentrations in tissues of pigeons did not decrease as atmospheric metal levels decreased. According to them, [11] ingestion may be more important than inhalation in exposing pigeons of $\mathrm{Pb}$ and $\mathrm{Cd}$ in this study.

Our results of $\mathrm{Zn}$ concentrations in femora of feral pigeons from Mitrovica $(198 \pm 110 \mu \mathrm{g} /$ g.d.w. $)$, and in Peja (urban area; $233 \pm 211 \mu \mathrm{g} / \mathrm{g}$. d. w.), are in accordance with results of Selimi [13], who in tibia, femora, liver, kidney and brain in population of pigeons living near lead and the Trepça zinc smelter, and in the population of pigeons from Prishtina, the capital of Republic of Kosovo, established higher concentrations of $\mathrm{Zn}$ 
in all above-analyzed tissues. Our recent results of $\mathrm{Zn}$ concentration in femora of Mitrovica pigeons are 0.8 times higher compared with the results of $\mathrm{Zn}$ concentrations recorded in pigeons of same area in $2000(165.3 \pm 28.4 \mu \mathrm{g} / \mathrm{g}$. d. w.), and 1.2 times lower in comparison with $\mathrm{Zn}$ concentrations in the femora in $2012(240 \pm 127 \mu \mathrm{g} / \mathrm{g}$. d. w.). On the other hand, the concentrations of $\mathrm{Zn}$ in femora of population of pigeons from Peja are 0.98 times higher in comparison with $\mathrm{Zn}$ concentrations in femora of Prishtina pigeons [13].

Hutton and Goodman 1980 [10] found higher concentrations of $\mathrm{Pb}$ in the bone of feral pigeons from three London sites: Chelsea $(669 \pm 4.5 \mu \mathrm{g} / \mathrm{g}$. $\mathrm{d}$. w.), Mortlake (281.1 $\pm 73.7 \mu \mathrm{g} / \mathrm{g}$. d. w.), and Heathrow $(107 \pm 27.5 \mu \mathrm{g} / \mathrm{g}$. d. w.). Zinc concentrations in the bone of feral pigeons from the above three London sites was: Chelsea (188.9 $\pm 5.4 \mu \mathrm{g} / \mathrm{g}$. d. w), Mort lake (160.7+14.9), and Heathrow $(143.5 \pm 13.4 \mu \mathrm{g} / \mathrm{g}$. d. w.). They also established a significant correlation between lead and zinc in bone at both Chelsea $\left(\mathrm{r}_{39}=0.484 ; \mathrm{p}<0.01\right)$ and Mortlake $\left(r_{13}=0.626 ; p<0.05\right)$. It is not thought that zinc co-accumulatiaon with lead in bone tissue of urban pigeons was related to any differences in dietary zinc intake, as zinc levels in the gut contents were similar in the two examined London populations.

Frantz [6] studied 4 metals $(\mathrm{Cu}, \mathrm{Cd}, \mathrm{Pb}$ and $\mathrm{Zn})$, in feral pigeons from 7 sites in urbanized Paris, and found metal concentrations in feathers 2-90 times higher for $\mathrm{Cd}$ than for other metals, while lead concentrations ranged from 5-20 $\mu \mathrm{g} / \mathrm{g}^{-1}$ d. W., $\mathrm{Cd} \quad 0.5-2 \mu \mathrm{g} / \mathrm{g}^{-1} \mathrm{~d}$. w., $\mathrm{Cu}$ 8-16 $\mu \mathrm{g} / \mathrm{g}^{-1}$ d. w. and $\mathrm{Zn} 140-300 \mu \mathrm{g} / \mathrm{g}^{-1}$ d. w. These figures suggest that studies on free-living synanthropic organisms should help us better understand ecological consequences of urban projects, sanitary risks associated with narrow cohabitation between humans and nature, local biodiversity conversation and more generally the relationship between humans and nature.

Beyer [25], in old and juvenile songbirds collected from contaminated mining and smelting sites in the southeastern Missouri Lead Mining District, found markedly greater $\mathrm{Pb}$ concentrations in blood, liver and kidney tissues than in songbirds from reference sites, by a factor of 8 in blood, 13 in liver and 23 in kidney $(\mathrm{P}<0.05)$.

Berglund [26] studied metal (As, Cd, Cu, Ni, Pb an Se) accumulation in passerine birds pied flycatchers (Ficedula hypoleuca), and great tit (Parus major), following almost 20 years of reduced metal emissions from the largest nonferrous smelter in Finland. Close to the industry, emission reductions resulted in reduced exposure to several of the elements and, more importantly, reduced accumulation by 58 to $98 \%$ in liver tissue, albeit showing significant tissue reductions, nestlings had elevated concentrations of arsenic, cadmium, lead and selenium close to the industry. Their study indicates that in environments with moderate duration of industrial activity, impact, and soil pollution, metal accumulation in organisms can decrease relatively rapidly when atmospheric emissions are reduced [27].

Due to urbanization, the increased trace metal elements in bird habitats are another major threat to local avifauna. Metals such as lead, iron and zinc contaminate air, soil and flora, and thus also bird diets [28]. Ingesting excess "essential elements" such as Zn, $\mathrm{Mn}$ and $\mathrm{Cu}$ can be harmful [29].

Studies of eight heavy metals (Al, Cr, Mn, Fe, $\mathrm{Cu}, \mathrm{Zn}, \mathrm{Cd}, \mathrm{Pb}$ ) in livers of house sparrows (Passer domesticus), from urban and rural habitats in southern Finland showed significantly higher concentrations of analyzed metals in livers of urban than in those of rural house sparrows [30]. $\mathrm{Zn}, \mathrm{Fe}, \mathrm{Mg}$, and $\mathrm{Mn}$, are essential for organisms at certain amounts, but become harmful when in excess. The amounts of heavy metals that are harmful depend on species, tissues and environmental factors, and specific knowledge is not always available [29].

Meillere, found that the burden of $\mathrm{Cd}$ and $\mathrm{Pb}$ increased with increasing urbanization in the common blackbird (Turdus merula) [31].

Thus, in areas with a history of metal pollution, the soil pool will have a greater impact at lower atmospheric emissions of metals. This may be one explanation for the higher concentrations of $\mathrm{Pb}$ in femora of feral pigeons from Mitrovica since 2000.

Undetected $\mathrm{Pb}$ concentrations in femora of feral pigeons from urban areas (Peja), is most likely a result of phasing out leaded petrol, which has been used in Kosovo since 2000.

\section{Conclusions}

From the perspective of avian metal accumulation, our results show that environmental contamination with heavy metals close to the former Trepça smelter in Mitrovica is improving, although complete recovery of the area in terms of reaching background of metals (especially for lead), has not yet been achieved. The higher accumulation of lead in femora of pigeons from Mitrovica draws attention to the potential hazard of lead in children from such an area. After 17 years, the vicinity of the former smelter still poses a threat to the local environment, biota and people's health. Feral pigeons can be useful organisms for chronic evaluation of environmental pollution with heavy metals.

\section{Conflict of Interest}

All the authors declare no conflict of interest.

\section{References}

1. LEE J., LEE J., PARK J.H., LEE E., SHIM K., JANG H., KIM M. The Characteristics of Heavy Metal Distributions 
in the Tissues of Feral Pigeon (Columba livia) as a Biomonitoring Indicator. J. Environ. Imp. Asses., 23, 492, 2016.

2. CAI F., CALISI R. M. Seasons and neighborhoods of high lead toxicity in New York City: The feral pigeon as a bioindicator. Chemosphere 161, 274, 2016.

3. CHATELAIN M, GASPARINI J., FRANTZ A. Do trace metals select for darker birds in urban areas? An experimental exposure to lead and zinc. Glob. Chng. Biol. Wil., 22 (7), 2380, 2015.

4. GUSHIT J.S.,TURSHAK L.G., CHASKDA A.A. ABBA B.R., NWAEZE U.P. Avian feathers as bio-indicator of heavy metal pollution in urban degraded woodland. Ewm. J. Analy. \& Environ. Chem., 2, 84, 2016.

5. ELEZAJ I.R., SELIMI Q.I., LETAJ K.RR., MILLAKU L.B. and SEFAJA L. Metal Accumulation, Blood $\delta$-Aminolevulinic Acid Dehydratase Activity and Micronucleated Erithrocytes of Feral pigeons (Columba livia) Living Near Former Lead-Zinc Smelter "Trepça"- Kosovo. E3S web Conf. 1, 34001. DOI:10.1051/ e3sconf/2013014001, 2013.

6. FRANTZ A., POTTIER M.A., KARIMI B., CORBEL H., AYBRY E., HAUSY C., GASPARINI J., CASTRECROUELLE M. Contrasting levels of heavy metals in the feathers of urban pigeons from close habitats suggest limited movements at a restricted scale. Environ. Poll., 168, 23, 2012.

7. JENNI L., MADRY M.M., KRAMER T.H., KUPPER J., NAEGLI H., JENNY H., JENNY D. The frequency distribution of lead concentration in feathers, blood, bone, kidney and liver of golden eagles Aquila chrysaetos: insights into the modes of uptake. J. Ornith, DOI 10.1007/ s10336-015-1220-7. 2015

8. KITOWSKI I., JAKUBAS D., WIACEK D., SUJAK A. Concentrations of lead and other elements in the liver of the white-tailed eagle (Haliaeetus albicilla), a European flagship species, wintering in Eastern Poland. Ambio, 46 (8), 825, 2017.

9. PRZYBYLSKA K., HAIDT A., MYCZKO Ł., EKNERGRZYB A., ROSIN Z.M. et al. Local and landscapelevel factors affecting the density and distribution of the feral pigeon Columba livia var. domestica in an urban environment. Act. Ornith., 47, 37, 2012.

10. HUTTON, M., GOODMAN G.T. Metal contamination of feral pigeons Columba livia from London area: Part I-Tissue accumulation of lead, cadmium and zinc. Environ. Poll., Ser. A, 22, 207, 1980.

11. NAM D.H., LEE D.P. Reproductive effects of heavy metal accumulation on breeding feral pigeons (Columba livia). Sci. Tot. Environ., 366, 682, 2006.

12. ELEZAJ I.R., SELIMI Q.I., LETAJ K.RR. The accumulatin of $\mathrm{Pb}, \delta$ - aminolevulinic acid dehydratase, hematocrit and hemoglobine amount of Feral pigeons (Columba livia) living near lead and zinc smelter "Trepça" in Mitrovica- Kosovo-Four year study. Procedings of the $14^{\text {th }}$ International Conference of the Heavy Metals in the Environment. Taipei. ISBN 978-98601-5851-9, 2008.

13. SELIMI Q.I., ELEZAJ I.R., LETAJ K.Rr. Letaj. Tissue accumulation of $\mathrm{Pb}$ of $\mathrm{Pb}, \delta$-aminolevulinic acid dehydratase, hematocrit and hemoglobine amount in blood of Feral pigeons (Columba livia) living in Prishtina the capital of Kosovo (Four year study). Procedings of the $14^{\text {th }}$ International Conference of the Heavy Metals in the Environment., Taipei, Taiwan, 1, 257, 16-23 September, 2008.
14. ELEZAJ I.R., SELIMI Q.I., LETAJ K.RR., MILLAKU L.B., SEFAJA L. Metal accumulation, blood $\delta$-aminolevulinic acid dehydratase activity and micro nucleated erythrocytes of feral pigeons (Columba livia) living near former lead-zinc smelter Trepça-Kosovo. Proceedings of the 16th International Conference on Heavy Metals in the Environment. Rome, Italy, 1, 23, September, 2012.

15. BORGNA L., DI LELLA L.A., NANNONI F., PISANI A., PIZZETTI E., PROTANO G., RICCOBONO F., ROSSI S. The high contents of lead in soils of northern Kosovo. J. Geochem. Explor., 101,137, 2009.

16. ŠAJN R., ALIU M., STAFILOV T., ALIJAGIC J. Heavy metal contamination of topsoil around a lead and zinc smelter in Mitrovicë, Kosovo. J. Geochem. Explor., 134, 1, 2013.

17. MILLAKU L., IMERI R., TREBICKA A. Bioaccumulation of heavy metals in tissues of House sparrow (Passer domesticus). Res. J. of Environ. Toxic., 9 (2), 107, 2015.

18. NAM D.H., ANAN Y., IKEMOTO T., OKABE Y., KIM E.Y., SUBRAMANIAN A., SAEKI K., TANABE S. Specific accumulation of 20 trace elements in great cormorants (Phalacrocorax carbo), from Japan. Environ. Poll., 134 (3), 503, 2005.

19. MORA M. Heavy metals and metalloids in egg contents and eggshells of passerine birds, from Arizona. Environ. Poll., 125, 393, 2003.

20. BLUM J.D., TALIAFERRO E.H., WEISSE M.T., HOLMES R.T. Changes in $\mathrm{Sr} / \mathrm{Ca}, \mathrm{Ba} / \mathrm{Ca}$ and $87 \mathrm{Sr} / 86 \mathrm{Sr}$ ratios between trophic levels in two forest ecosystems in the northeastern U.S.A. Biogeochemistry, 49, 87, 2000.

21. BUDIS H., KALISINSKA E, LANOCHA N., KOSIKA-BUGACKA D.I. The Concentration of Manganese, Iron and Strontium in Bone of Red Fox Vulpes vulpes (L. 1758). Biol. Trc. Elem. Res., 155 (3), 361, 2013.

22. ELEZAJ R.I., MEMISHI SH., SELIMI Q.I., LETAJ K.RR., MEMETI S. Seasonal Affects of Environmental Heavy metal Pollution on Tissue Accumulation of Lead, Abstracts Cadmium, Copper and Zinc in House Sparrow (Passer domesticus). 15 $5^{\text {th }}$ International Conference on Heavy metals in the environment, Gdansk, Poland, 19-23 September, 2010.

23. ELEZAJ I., SELIMI I.Q., LETAJ K., PLAKIQI A., MEHMETI I.S., MILAIMI A. Metal Bioaccumulation, Enzymatic Activity, Total Protein and Hematology of Feral Pigeon (Columba Livia), Living in the Courtyard of Ferronickel Smelter in Drenas. J. Chem. Hlth. Risks, 1 (1), 01, 2011.

24. MIETELSKI J.W., KITOWSKI I., GACA P., FRANKOWSKA P., TOMANKIEWICZ E., BLAZEJ S., KIEREPKO R. Radionuclides in bones of diurnal birds of prey and owls from the Eastern Poland. Chem. Anal. (Warsaw), 53, 821, 2008.

25. BEYER N.V., FRANSON J.CH., FRENCH J.B., MAY TH., RRATNER B.A. Toxic exposure of songbirds to Lead in the Southeast Missouri Lead Mining District. Arch Environ. Contam. Toxicol., 65, 598, 2013.

26. BERGLUND A.M.M., RAINIO M.J., EEVA T. Decreased metal accumulation in passerines as result of reduced emissions. Environ. Toxicol. and Chem., 31 (6), 1317, 2012.

27. BERGLUND A.M.M., RAINIO M.J., EEVA T. Temporal Trends in Metal Pollution: Using Bird Excrement as Indicator. PLoS ONE 10(2), e0117071, 2015. 
28. KIM J., OH J.M. Assessment of Trace Element Concentrations in Birds of Prey in Korea. Arch. Environ. Contam. Toxicol., 71 (1), 26, 2016.

29. FRANSON J.C., LATNER L.L., METEYER C.U., RATTNER B.A. Copper Pellets Simulating Oral Exposure to Copper Ammunition: Absence of Toxicity inAmerican Kestrels (Falco sparverius). Arch. Environ. Contam. Toxicol., 62, 145, 2012.

30. KEKKONEN J., HANSKI I.K., VAISANEN R.A., BROMMER J.E. Levels of heavy metals in House
Sparrows (Passer domesticus), from urban and rural habitats of southern Finland. Ornis Fenn., 89, 91, 2012.

31. MEILLERE A., BRISCHOUX F., BUSTAMANTE P., MICHLAUD B., PARENTEAU CH., MARCIAU C., ANGELIER F. Corticosterone levels in relation to trace element contamination along an urbanization gradient in the common blackbird (Turdus merula). Sci. of Tot. Environ., 566, 93, 2016. 